\title{
GENOTOXICITY ASSESSMENT OF THE GROUNDWATER QUALITY IN THE TEBOULBA REGION-TUNISIA USING THE VICIA FABA MICRONUCLEUS TEST
}

\author{
SOUGUIR, D. ${ }^{1 *}-$ HÖRMANN, G. ${ }^{2}-$ HACHICHA, M. ${ }^{1}$ \\ ${ }^{1}$ Institut National de Recherches en Génie Rural, Eaux et Forêts (INRGREF) \\ Université de Carthage, Rue Hédi Karray, Manzeh IV, 2080-Ariana, Tunisie \\ ${ }^{2}$ Department of Hydrology and Water Resources Management, Kiel University, Germany \\ *Corresponding author \\ e-mail:souguir.dalila@yahoo.com \\ (Received $2^{\text {nd }}$ Nov 2018; accepted $28^{\text {th }}$ Jan 2019)
}

\begin{abstract}
The groundwater of the Teboulba region in Tunisia suffers from overexploitation and from the degradation of its quality due to salt water intrusion from the Mediterranean sea as well as from the sebkha of Moknine. The actual groundwater quality was assessed using the Vicia faba root meristem micronucleus assay. The exposure of $V$. faba to irrigation water from 3 wells showed no spectacular changes in the root growth, fresh and dry matter and the membrane integrity compared to the control plants. However, the plants exhibited decreases in their mitotic index and high inductions of micronuclei and chromosomal aberrations including stickiness, bridges, fragments, vagrant chromosomes and laggards. Consequently, and despite the fact that the morphological parameters and the membrane integrity did not show noticeable variation, the micronucleus test has proved to be an early bioassay allowing the detection of the Teboulba groundwater genotoxicity, which may probably result from contamination of the groundwater by agricultural and industrial activities in/or surrounding the region.

Keywords: aberrations, contamination, membrane integrity, micronucleus, mitotic index, morphological parameters, Teboulba groundwater
\end{abstract}

\section{Introduction}

The groundwater is considered as the primary resource for water. It is widely used for agriculture and industry especially in regions with limited annual precipitation. However, shallow groundwater is vulnerable to various types of pollution. In fact, in coastal regions, the overuse of groundwater wells located near the shoreline is the major cause of the salt water intrusion in the groundwater (Bouri and Ben Dhia, 2010). This phenomenon is considered as the primary cause of the salinization of groundwater (Bear et al., 1999). Moreover, groundwater contamination with anthropogenic materials is possible, harming both the groundwater quality and quantity. Such materials dissolve in the liquid phase, and may penetrate into the soil and affect the groundwater quality via percolation (Bear and Cheng, 2010). The groundwater quality may also suffer from other contamination like septic tanks and wastewater effluents. There are different types of pollutants that can be found in the groundwater such as salt, nitrate, heavy metals and new contaminants like pharmaceuticals and personal care products (Zghibi et al., 2013; Ameur et al., 2016; Ouessar et al., 2017).

In Tunisia, numerous irrigation regions are located near the coast where extensive areas have evolved into an advanced agricultural production zone with considerable economic importance. However, the agricultural practices in these regions have already led to the overexploitation of the groundwater resources and an increased salinity by seawater or saline water intrusion. Additional groundwater contamination was caused 
by industrial activity, applications of artificial fertilizers, manures, pesticides and irrigation with treated wastewater in many Tunisian coastal regions (Saidi et al., 2013; Fries et al., 2016; Dahmouni et al., 2017). 750 sources of contamination of urban, industrial and agricultural origins were identified. They cause significant damage to the Tunisian water resources according to the national inventory established in 2004 by the Ministry of the Environment and Sustainable Development (Besbes et al., 2013). These sources include alimentary, textile and plastic industry sectors and domestic and industrial treated wastewater, the quality of which frequently exceeds the Tunisian standard.

Teboulba is a Tunisian coastal region with a long tradition of highly profitable irrigated agriculture. Like most coastal zones with shallow groundwater, the Teboulba region suffers from overexploitation caused by intensive pumping that led both to a decrease of the water level and to an increase of salinity. It caused salt water intrusion from the Mediterranean sea as well as from the sebkha of Moknine, an endorheic and salty depression resulting from Quaternary tectonic events (Chairi et al., 2010) which was used as a discharge site for many industrial activities (Wali et al., 2015). There is not much known about the current state of the groundwater, only measurements of water and salinity levels during and a few years after the artificial recharge from the overspill of the Nebhana dam and its injection into a limited number of wells (Bouri and Ben Dhia, 2010). Even if there is no recent information about the quality of the Teboulba groundwater, there are increasing complaints about the poor quality of the irrigation water. Therefore, a short-term laboratory study has been carried out with the root meristem of Vicia faba plants to evaluate the genotoxicity potential as an indicator of the groundwater quality. The $V$. faba test has widely been used to detect and evaluate toxic elements and has commonly been regarded as an excellent genetic model for toxicity monitoring since it offers a detection of the DNA damage and/or DNA abnormalities in cell division. The fast and sensitive $V$. faba test enables to assess the mitotic index, the micronucleus formation, and the chromosome and the nuclear aberrations. This test was used to assess the genotoxicity of waters collected from 3 wells used for irrigation when water from Nebhana dam is unavailable. The aim of this paper is therefore to evaluate the genotoxicity of the irrigation water and this get an overview of potential quality problems.

\section{Materials and methods}

\section{Study area}

The experiment was carried out in the Teboulba region situated in the Monastir governorate (Tunisia), some tens of kilometers southeast of the city of Monastir (Fig. 1). The Teboulba region belongs to the Nebhana irrigation district where water scarcity remains an important issue. This region has a semiarid to arid climate with mild, wet winters and dry, hot summers. The mean annual rainfall is approximately of $375 \mathrm{~mm}$ and the mean annual temperature is about $20^{\circ} \mathrm{C}$. The coastal Teboulba aquifer is confined between the sea in the north and the salinized sebkha of Moknine in the south. It is threatened by overexploitation causing a decreasing water level and increasing salinization due to the seawater and/or sebkha intrusions. The aquifer basin of Teboulba covers approximately $35 \mathrm{~km}^{2}$ and represents an average hydrological recharge potential of $0.65 \mathrm{Mm}^{3} \mathrm{y}^{-1}$ with an exploited volume of $1 \mathrm{Mm}^{3} \mathrm{y}^{-1}$. This heavy deficit of $0.35 \mathrm{Mm}^{3} \mathrm{y}^{-1}$ is compensated not only by reserves but also by an inflow of 
saltwater from the sea and/or the sebkha as well as by a return flow of the irrigation water from the neighboring regions (Beni-Akhy, 1998).

The total agricultural area in Teboulba is 1914 ha, of which 600 ha are irrigated. In the governorate of Monastir, 39\% (572 ha) of the total land area are reserved for greenhouses, almost one third of this lies in the Teboulba region (CRDA, 2004). The agricultural sector is dominated by rain-fed olive plantations for olive oil production and horticulture in non-warmed greenhouses. The main water source for irrigation is the Nebhana dam. Each farm in the irrigation perimeter was equipped by a storage tank. Irrigation water prices in Teboulba are among the highest in Tunisia (Chebil et al., 2010). To minimize the water cost, farmers mixed the water from the dam with water pumped from their wells.

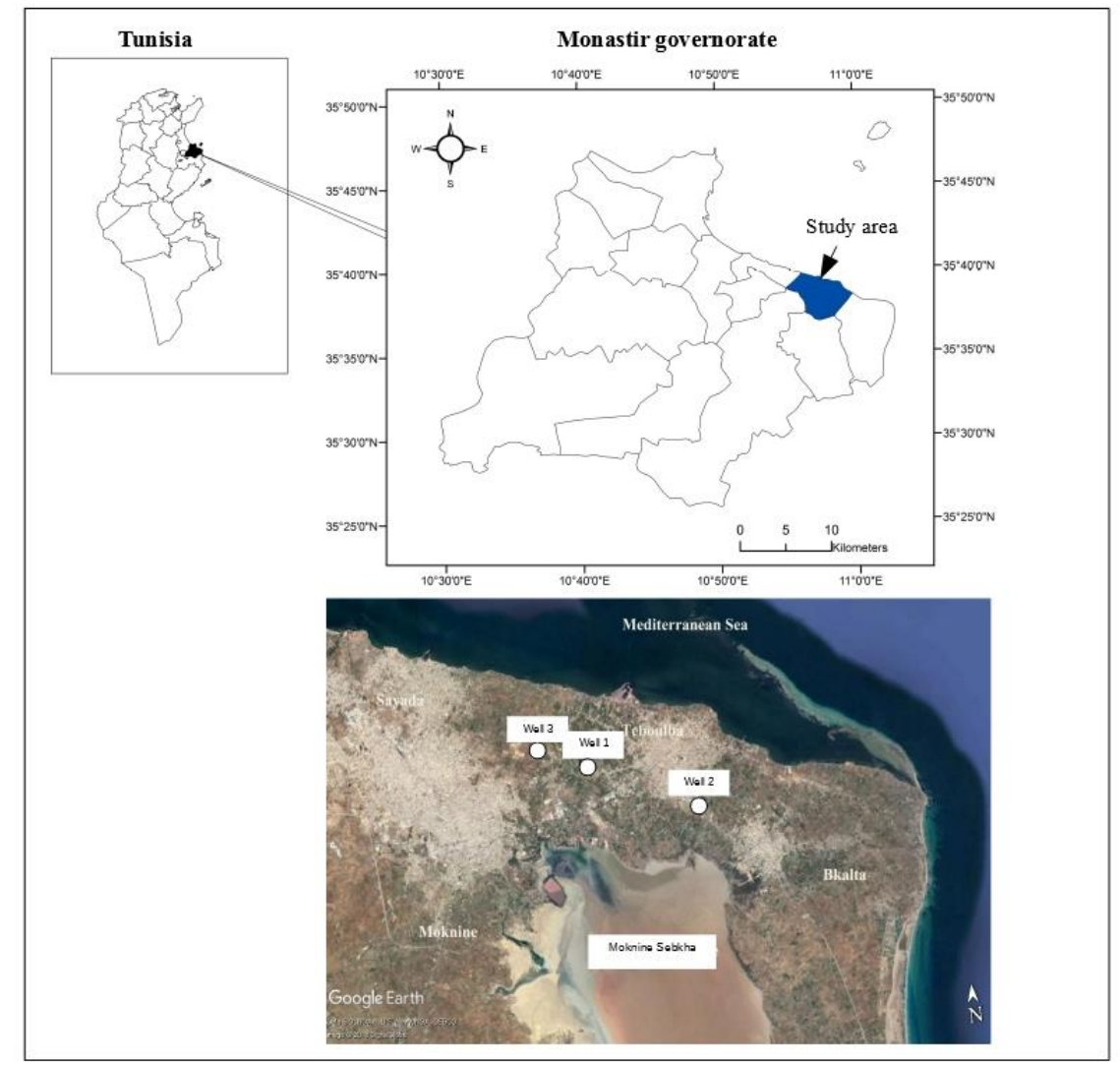

Figure 1. Study area and location of the 3 sampling wells

The present study was carried out in 2017 and with the most frequently used well of 3 farms from the irrigation perimeter with poor water quality in their wells (Fig. 1). The coordinates of the 3 wells (in Degrees Minutes Seconds) are: $35^{\circ} 38^{\prime} 49.94^{\prime \prime} \mathrm{N}$ and

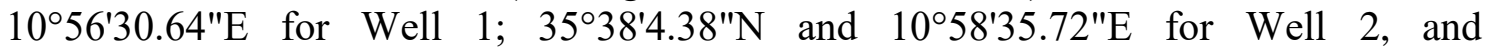
$35^{\circ} 38^{\prime} 49.88^{\prime \prime} \mathrm{N}$ and $10^{\circ} 55^{\prime} 37.52^{\prime \prime} \mathrm{E}$ for Well 3. The well depths were measured and water samples were collected, $\mathrm{pH}$ and electrical conductivity (EC) were measured with a $\mathrm{pH}$ meter (Lutron pH-211) and a conductivity meter (Cond./TDS, AZ 8361), respectively. Mineral composition was determined using the following methods: sodium $\left(\mathrm{Na}^{+}\right)$and potassium $\left(\mathrm{K}^{+}\right)$with flame emission spectrophotometry (Jenway, PFP7), calcium $\left(\mathrm{Ca}^{2+}\right)$ and magnesium $\left(\mathrm{Mg}^{2+}\right)$ with complexometric titration using a 
standardized solution of ethylenediaminetetraacetic acid (EDTA), chloride $\left(\mathrm{Cl}^{-}\right)$and bicarbonate $\left(\mathrm{HCO}_{3}{ }^{-}\right)$by titrating with silver nitrate $\left(\mathrm{AgNO}_{3}\right)$ and sulfuric acid $\left(\mathrm{H}_{2} \mathrm{SO}_{4}\right)$, respectively, and sulphate $\left(\mathrm{SO}_{4}{ }^{2-}\right.$ ) with UV-Visible spectrophotometer (Up Lab, UVVis-Auto). The 3 wells extracted the shallow groundwater at depths ranging between 27.5 and $44 \mathrm{~m}$ (Table 1). The water used for irrigation had a $\mathrm{pH}$ between 7.93 and 8.01 and a considerable salt content. The highest salinity was $7.26 \mathrm{dS} \mathrm{m}^{-1}$, found in Well 1 and the lowest salinity was $3.60 \mathrm{dS} \mathrm{m}$, recorded in Well $3 . \mathrm{Cl}^{-}$and $\mathrm{Na}^{+}$were the dominating ions at all salinity levels.

Table 1. Characterization of water collected from the 3 wells in the region of Teboulba

\begin{tabular}{c|c|c|c}
\hline & Well 1 & Well 2 & Well 3 \\
\hline Depth (m) & 27.5 & 29 & 44 \\
\hline $\mathbf{p H}$ & $7.97 \pm 0.06$ & $7.93 \pm 0.02$ & $8.01 \pm 0.04$ \\
$\mathbf{E C}\left(\mathrm{dS} \mathrm{m}^{-1}\right)$ & $7.26 \pm 0.08$ & $5.82 \pm 0.19$ & $3.60 \pm 0.15$ \\
$\mathbf{N a}^{+}\left(\mathrm{me} \mathrm{l}^{-1}\right)$ & $37.75 \pm 4.26$ & $31.78 \pm 4.01$ & $25.06 \pm 0.97$ \\
$\mathbf{C a}^{2+}\left(\mathrm{me} \mathrm{l}^{-1}\right)$ & $21.33 \pm 3.88$ & $15.66 \pm 0.57$ & $8.83 \pm 1.44$ \\
$\mathbf{M g}^{2+}\left(\mathrm{me} \mathrm{l}^{-1}\right)$ & $15.16 \pm 4.64$ & $11.00 \pm 2.00$ & $4.66 \pm 2.51$ \\
$\mathbf{K}^{+}\left(\mathrm{me} \mathrm{l}^{-1}\right)$ & $0.31 \pm 0.01$ & $0.24 \pm 0.00$ & $0.16 \pm 0.00$ \\
$\mathbf{C l}^{-}\left(\mathrm{me} \mathrm{l}^{-1}\right)$ & $34.78 \pm 0.81$ & $29.61 \pm 2.44$ & $19.74 \pm 7.05$ \\
$\mathbf{H C O}^{-}\left(\mathrm{me} \mathrm{l}^{-1}\right)$ & $4.66 \pm 0.76$ & $7.00 \pm 0.50$ & $6.01 \pm 0.00$ \\
$\mathbf{S O}_{4}^{2-}\left(\mathrm{me} \mathrm{l}^{-1}\right)$ & $30.39 \pm 9.40$ & $17.63 \pm 6.18$ & $8.56 \pm 2.09$ \\
\hline
\end{tabular}

\section{Plant treatments}

The $V$. faba seeds (Tunisian Chahbi variety) were surface sterilized with $10 \%$ sodium hypochlorite, rinsed several times with water and placed on moistened filter paper at $25^{\circ} \mathrm{C}$ for 3 to 4 days. Subsequently, the roots were introduced in both distilled water (control) and 3 samples of water collected from the 3 wells. For the genotoxicity assessment, a positive control was added. After 24 hours of exposure, the seedlings were rinsed a few times with distilled water and divided into three groups: the first was used for the growth measurement; the second to determine the membrane integrity and the third for the micronucleus test.

\section{Growth parameters}

Control and treated seedlings were separated into roots and epicotyls for root length, fresh and dry matter measurement. Root length was determined by measuring the length of the whole root after the treatments and dry matter was determined after drying the plant parts at $65^{\circ} \mathrm{C}$. At least 6 seedlings were used for the measurement of the growth parameters.

\section{Assessment of the plasma membrane integrity loss}

The loss of plasma membrane integrity was evaluated with three root tips by a spectrophotometric test using Evans blue (an indicator for the measure of the plasma membrane integrity) as described by Souguir et al. (2011). The first centimeter of the roots was incubated in $0.025 \%$ Evans blue $(\mathrm{m} / \mathrm{v})$ for $30 \mathrm{~min}$, rinsed for $15 \mathrm{~min}$ and squashed in a $800 \mu \mathrm{l}$ solution of $50 \%$ of $\mathrm{MeOH}(\mathrm{v} / \mathrm{v})$ and $1 \%$ of sodium dodecyl sulphate (SDS). The root extracts were then incubated for $15 \mathrm{~min}$ at $50^{\circ} \mathrm{C}$. The homogenate was centrifuged at 14,000 rpm for $15 \mathrm{~min}$. The optical density of the supernatant was determined spectrophotometrically at $600 \mathrm{~nm}$. 


\section{Genotoxicity assessment}

The genotoxicity of the water from the 3 wells and the control was assessed with the micronucleus test applied on the meristematic roots of $V$. faba plant. A positive control with the hydrazide maleic (HM, $410^{-3} \mathrm{M}$ ) was added since the HM is well-known for its induction of numerous and very easily observable micronuclei (Souguir et al., 2008; Cotelle et al., 2015). The root tips were cut, placed overnight in a Carnoy's fixation solution containing ethanol and glacial acetic acid (3/1), and stored in the dark in $70 \%$ of ethanol before being hydrolyzed with $1 \mathrm{~N} \mathrm{HCl}$ as described by Souguir et al. (2008). The root meristematic tissues were stained with orcein, squashed between a slide and a coverslip, and finally examined under a research microscope (Leica DM2500) with 40 or 100 times magnification.

Three slides were prepared for each of the three replicates and a total of 9,000 cells were observed. The mitotic index (MI) was expressed as the number of dividing cells in 100 observed cells. Micronuclei were observed in both the interphasic and the mitotic cells. Only micronuclei observed in interphases were counted and expressed in terms of micronuclei per 1,000 interphase cells.

Chromosomal abnormalities were photographed with a digital camera (Canon EOS 1100) attached to the microscope.

\section{Statistical analysis}

The results were presented as the mean \pm standard deviation (SD) obtained from three replicates. Significant differences were determined by Tukey's test at the $0.05 \%$ confidence level with the SPSS software (IBM SPSS statistics, v20).

\section{Results}

\section{Morphological parameters and membrane integrity}

The morphological parameters, root growth and fresh and dry matters of the different Vicia organs (root and epicotyl), are illustrated in Table 2. In general, the plants exposed to the water from wells and control did not show any significant difference in terms of root length. The average length varied between 3.92 and $5.22 \mathrm{~cm}$. Fresh and dry matter of the plants irrigated with the water from the wells did not differ from the control plants.

The root treatment with Evans blue indicator also did not show a change of membrane integrity loss between the control and the roots (Fig. 2).

\section{Genotoxicity data}

Figure 3 lists the genotoxicity data of the 3 wells. The MI related to the number of cells undergoing division was higher in the control cells (exposed to distilled water) and reached $37 \%$, whereas the $\mathrm{HM}$ as a positive control decreased severely the mitotic activity. This decline also occurred in the roots exposed to all kinds of irrigation waters. Values oscillated between $7 \%$ in well 3 and 14\% in Well 1. In addition, cells supporting a micronucleus were counted. Low micronucleus frequencies $(0.2$ micronucleated cells per 1,000 counted cells) were recorded in the root tips of the control plants. As expected, the HM treatment sharply increased the frequency of micronuclei (21.8 micronucleated cells per 1,000 counted cells) compared to the control. The well water significantly increased the frequency of micronucleus formation in the root cells 
of $V$. faba. The highest frequency of micronucleus ( 7.15 micronucleated cells per 1,000 scored cells) was detected in Well 1, while the lowest level (5.75 micronucleated cells per 1,000 scored cells) was noticed in Well 3.

Table 2. Growth parameters of the V. faba exposed to water collected from the 3 wells

\begin{tabular}{|c|c|c|c|c|}
\hline & Control & Well 1 & Well 2 & Well 3 \\
\hline Root length $(\mathrm{cm})$ & $4.560 \pm 0.996 \mathrm{a}$ & $3.928 \pm 1.071 \mathrm{a}$ & $4.925 \pm 0.869 \mathrm{a}$ & $5.225 \pm 1.252 \mathrm{a}$ \\
\hline \multicolumn{5}{|c|}{ Fresh matter (g) } \\
\hline Root & $0.234 \pm 0.051 \mathrm{a}$ & $0.272 \pm 0.073 \mathrm{ab}$ & $0.367 \pm 0.079 \mathrm{~b}$ & $0.248 \pm 0.069 \mathrm{ab}$ \\
\hline Epicotyl & $0.301 \pm 0.082 \mathrm{a}$ & $0.366 \pm 0.110 \mathrm{ab}$ & $0.488 \pm 0.088 \mathrm{~b}$ & $0.326 \pm 0.065 \mathrm{ab}$ \\
\hline \multicolumn{5}{|c|}{ Dry matter (g) } \\
\hline Root & $0.016 \pm 0.003 \mathrm{a}$ & $0.018 \pm 0.008 \mathrm{a}$ & $0.026 \pm 0.005 \mathrm{a}$ & $0.018 \pm 0.005 \mathrm{a}$ \\
\hline Epicotyl & $0.026 \pm 0.006 \mathrm{a}$ & $0.033 \pm 0.009 \mathrm{ab}$ & $0.045 \pm 0.008 \mathrm{~b}$ & $0.029 \pm 0.006 \mathrm{a}$ \\
\hline
\end{tabular}

Values are means \pm SD. Different letters indicate significant differences at $P<0.05$ according to Tukey's test

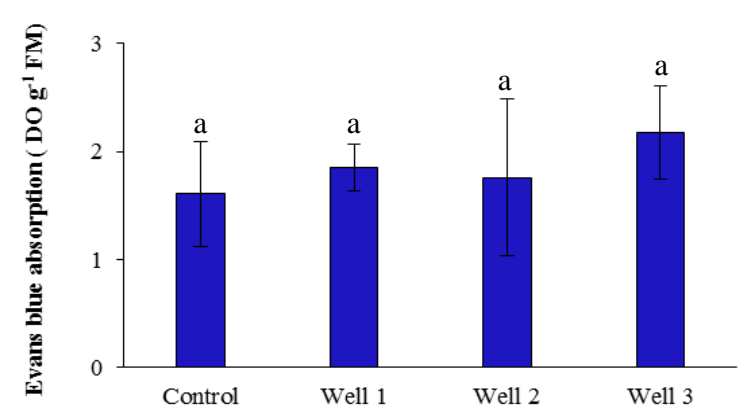

Figure 2. Plasma membrane integrity as determined by Evans blue absorption of V. faba root extracts while exposed to water collected from the wells. Values are means $\pm S D$. Same letters indicate no significant differences at $P<0.05$ according to Tukey's test
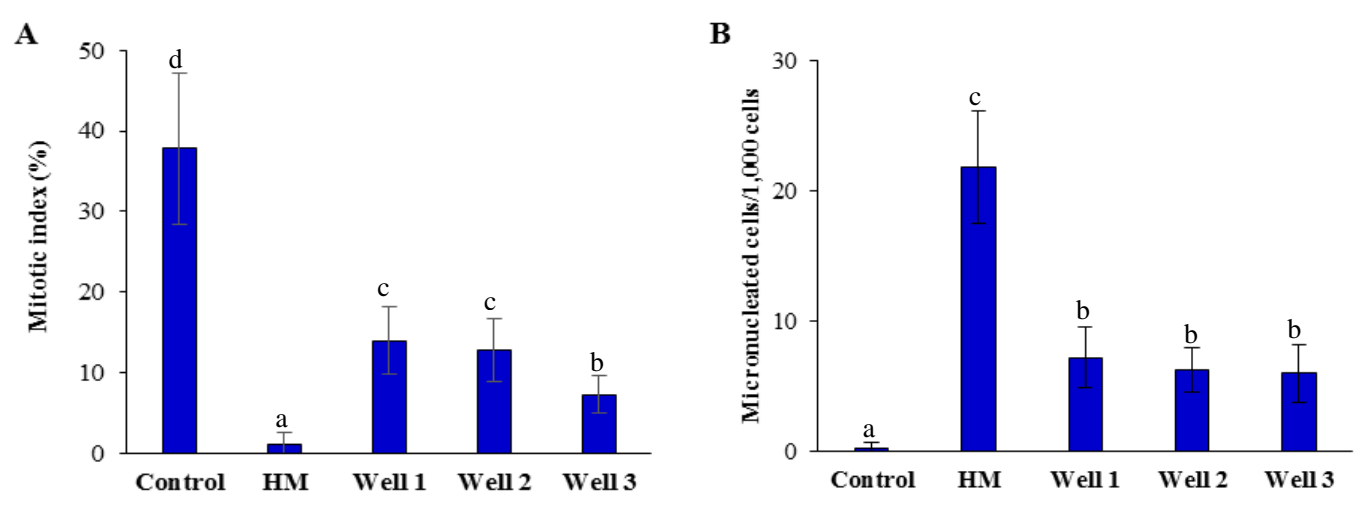

Figure 3. Mitotic index (\%) (A) and interphasic cells showing micronuclei (B) induced under exposure to different qualities of water collected from the studied wells. Control: negative control with distilled water; HM: positive control with Hydrazide maleic. Values are means \pm

$S D$. Different letters indicate significant differences at $P<0.05$ according to Tukey's test 


\section{Chromosomal abnormalities}

The root cells of $V$. faba treated with the 3 water qualities showed various types of chromosomal aberrations (Fig. 4). The cytological aberrations recorded in the bean root tips were stickiness at the prophase, bridges at the anaphase, fragments at the anaphase and the telophase, and finally vagrant chromosomes and laggards at the anaphase and the telophase.

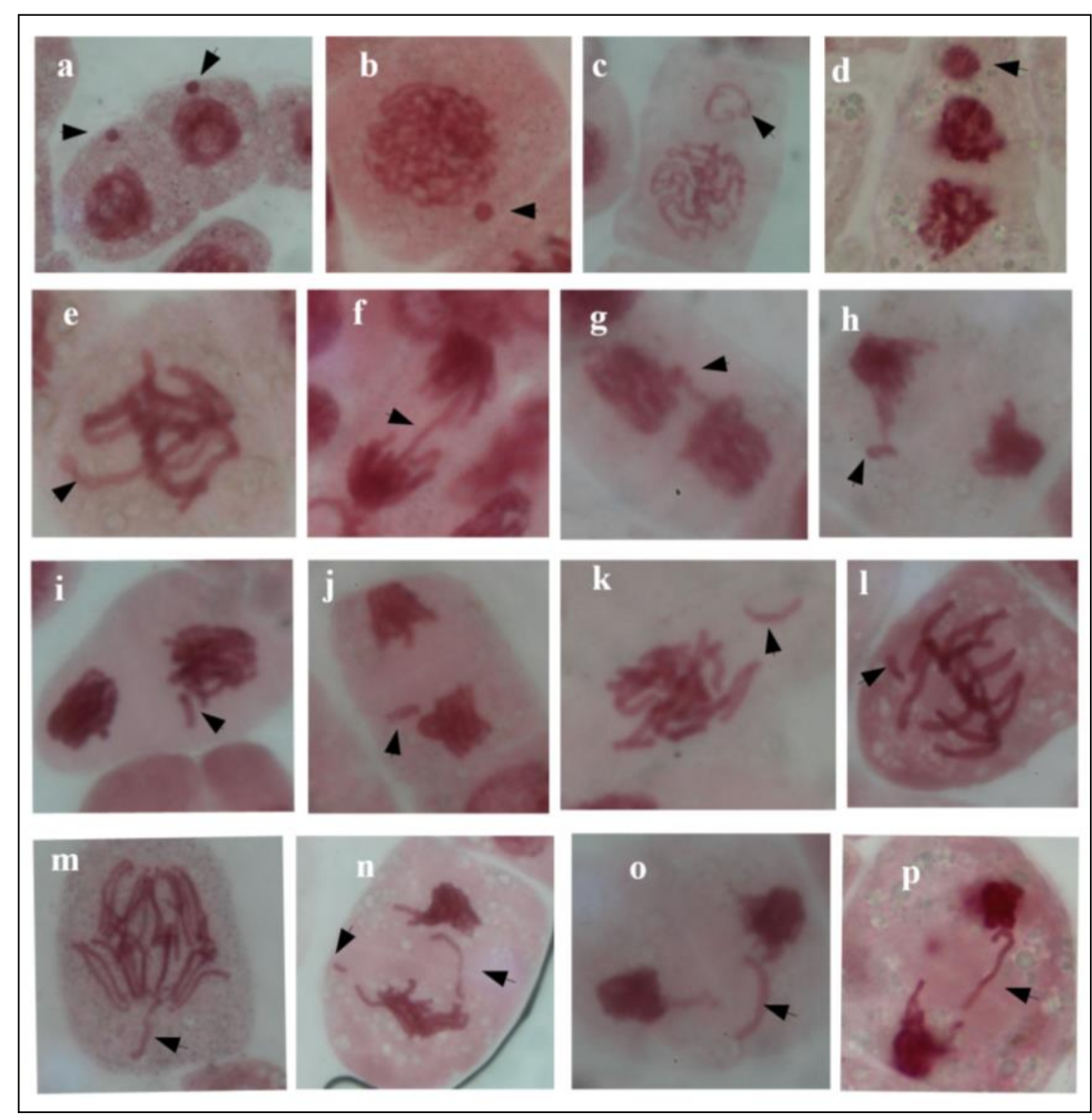

Figure 4. Chromosomal aberrations detected in the root-meristematic zone of $V$. faba exposed to the water collected from the studied wells. $\boldsymbol{a}$ - interphasic cells with a micronucleus; $\boldsymbol{b}$ -

prophase with a non-synchronized micronucleus; $\boldsymbol{c}$ - prophase with a synchronized micronucleus; $\boldsymbol{d}$-telophase with a micronucleus; $\boldsymbol{e}$ - stickiness; $\boldsymbol{f}$-g-bridge; $\boldsymbol{h}$-j- fragment; $\boldsymbol{k}$-l vagrant chromosome; $\boldsymbol{m}$ - abnormal anaphase; $\boldsymbol{n}$-chromosome laggard (1) and fragment (2); $\boldsymbol{p}$ q- chromosome laggard; (magnification: 1000x)

\section{Discussion}

The water quality used to irrigate the Teboulba parcels was evaluated by analyzing root morphology, membrane integrity and by screening genotoxicity. $V$. faba showed no changes in their morphological parameters (root growth, fresh and dry matters) between control plants and those exposed to the tested well water. The same results were obtained for membrane integrity measured by the Evans blue uptake. However, several effects were observed in the Vicia meristematic root tips on genotoxic parameters, estimated by MI, a micronucleus induction band, and some chromosome abnormalities. 
A significant retardation in the MI was remarked for all treatments compared to the control, which indicates the presence of cytotoxic substances in the irrigation water causing inhibition of the mitotic activity (Fernandes et al., 2007). The cell division inhibition could result from an arrest of the DNA synthesis or a blocking in the G2 phase of the cell cycle, preventing the cell from entering mitosis (Sudhakar et al., 2001). It could also be caused by an impaired nucleoprotein synthesis and a reduced level of ATP to provide energy for spindle assembly and chromosomal movements (Majewsk et al., 2003).

Micronuclei were considered as an indication of a true mutation effect (Auerbach, 1962). Thus, the high percentage of micronuclei induced may indicate the mutagenic effect of contaminants in the tested samples. Micronuclei detected in interphasic cells may originate from acentric chromosome fragments, acentric chromatid fragments or whole chromosomes that fail to be included in the daughter nuclei at the completion of the telophase during mitosis (Fenech, 2011). Micronuclei may also be generated by the elimination of exceeding genetic material from the main nucleus (Fernandes et al., 2007). In addition to micronucleus appearance, many chromosomal aberrations in different mitotic phases including bridges, fragments, stickiness, vagrants and laggards were noticed in cells exposed to the irrigation waters. The induction of such aberrations in the bean root tip meristems indicates that the well water probably contains genotoxic chemical constituents with clastogenic and aneugenic impacts: The clastogenic compounds may induce a disruption or a breakage of chromosomes, whereas the aneugenic ones may result in a tubule formation or a chromosome segregation errors (Parry et al., 2002; Bignold et al., 2009).

The high salinity in the well water $\left(3.60-7.26 \mathrm{dS} \mathrm{m}^{-1}\right)$ may lead to such mutagenic/genotoxic effects. The effect of salt on micronucleus induction and on chromosome changes was recently assessed in the Vicia root tips treated with $25 \mathrm{dS} \mathrm{m}^{-1}$ of $\mathrm{NaCl}$ (Souguir et al., 2018). The salt treatment caused micronuclei and changed the organization and the morphology of chromosomes and nuclei. It was shown for salinity values close to those in the Teboulba wells (Teerarak et al., 2009) that the cytotoxicity could be attributed to salinity.

In addition to salt-induced DNA damages, the genotoxicity may be caused by contaminants released from the sebkha of Moknine into the Teboulba groundwater. The sebkha of Moknine, a salty coastal depression, is considered as a hotspot of the industrial activities in the region. One of the most significant sectors in the Monastir region is the textile industry with about 917 factories. This industry is considered to be the most polluting sector of all industries (Garg and Kaushik, 2007; Sarker et al., 2015). About 24 tanneries discharge their effluents on the open land of the sebkha of Moknine and into the surrounding water bodies. Other industries such as blue jeans dyeing, printing industries and washing companies, also release their sewage directly and/or indirectly into the sebkha (Wali et al., 2015). The extensive use of dyes in textile industries and the release of effluents containing toxic compounds can harm soil, water and the living systems including human beings (Minhaz et al., 2018; Vega-Negron et al., 2018). Using Allium cepa, known as sensitive as V. faba, Sudhakar et al. (2001) showed a marked lowering of the mitotic index (from 9 to 2.2\%) when germinating onion bulbs were immersed in $25,50,75,100 \%$ of silk industry dye effluents for 24 hours. Silk dyeing effluents were shown to be genotoxic due to presence of mitotic inhibitors like tannins and alkaloids (Rath and Sethi, 2017). 
The contribution of the textile industries as well as that of the potteries and the brick industry to the high pollution of the sebkha of Moknine has been previously pointed out through a sebkha sediment analysis (Wali et al., 2015). Moreover, the sebkha receives treated wastewaters from the treatment plants of Moknine, which treat domestic $(50 \%)$ and pretreated industrial (50\%) wastewater using naturally aerated lagoons as secondary treatment process (Rafraf et al., 2016). Effluents from textile industries, brick kilns as well as industrial and household wastewater treatment plants contain a high amount of heavy metals (Achakzai et al., 2015). These contaminants were found in the sebkha of Moknine and lead to groundwater contamination (Malarkodi et al., 2007).

Soil leaching may also contribute to the contamination of groundwater with heavy metals through the overuse of fertilizers, which are usually not completely removed during the production. Being an agricultural region providing nearly a third of the Monastir governorate production (CRDA Monastir, 2004), the use of fertilizers in order to improve soil fertility and plant production is a common agricultural practice in Teboulba. For instance, the cadmium (Cd) contained in $\mathrm{P}$ fertilizers may cause high contents in the soil (McLaughlin et al., 1996). Like other metals, Cd might be either absorbed by plants or leached to the groundwater. Its behavior in the soil, accumulation by crops or groundwater leaching depend on numerous factors such as $\mathrm{pH}$, organic matter, salinity, crop species and cultivar, etc. As a non-essential element, this metallic element is well-known for its genotoxic potential and many authors focused on its ability to decrease the MI value and to induce micronuclei and chromosomal aberrations. Souguir et al. (2011) investigated the cyto-mutagenic defects in $V$. faba root tip cells exposed to $\mathrm{CdCl}_{2}(10,100$ and $200 \mu \mathrm{M})$ for 24 hours. They found increased micronucleus incidences in exposed root cells and with severe mitotic activity decreases. Such effects were also reported by Ünyayar et al. (2006) with $\mathrm{Cd}\left(\mathrm{NO}_{3}\right)_{2}$ but for much longer exposure (48 hours) and by Beraud et al. (2007) under lower concentrations of $\mathrm{CdCl}_{2}(0.075-0.5 \mu \mathrm{M})$. Likewise, the genotoxic potential of many other heavy metals has been previously determined. $V$. faba has also been used to analyse mitotic activity decrease, micronuclei and chromosomal abnormality induction, which appeared when roots exposed to $0.5-1 \mathrm{mM}$ of $\mathrm{CrO}_{3}$ for 24 hours (Duan et al., 2013), $0.01-10 \mathrm{mM}$ of $\mathrm{AlCl}_{3}$ for 12 hours (Yi et al., 2009), and $0.005-0.01 \mathrm{mM}$ of $\left(\mathrm{Pb}\left(\mathrm{NO}_{3}\right)_{2}\right.$ for only 6 hours (Pourrut et al., 2011). Souguir et al. (2008) found that high concentrations of $\mathrm{Cu}(2.5-50 \mathrm{mM})$ were needed to increase significantly the micronuclei frequency in $V$. faba after 42 hours of exposure to $\mathrm{CuSO}_{4}$, while Steinkellner et al. (1998) found that neither $\mathrm{CuSO}_{4}$ nor $\mathrm{ZnCl}_{2}$ induced any significant changes of genotoxic parameters in $V$. faba root tips. Heavy metals as well as salinity are usually associated with oxidative stress and generation of reactive oxygen species (ROS), which may also be behind the genotoxicity observed in the water collected from the tested wells. ROS production could increase DNA alterations and DNA-repair inhibition at the origin of micronucleus (Valverde et al., 2001).

Excessive fertilization may also cause the high levels of nitrate detected in the groundwater of Grombalia, Korba and Sminja in the North- East of Tunisia, Bekalta and Mahdia-Ksour Essaf in the Center-East of Tunisia, and Sidi-Aïch Gafsa oases and Djerba in the South of Tunisia (Wakida and Lerner, 2005; Einschlag, 2011; Zghibi et al., 2013; Hamed et al., 2013; Ameur et al., 2016; Souid et al., 2017). Nitrate concentrations can be caused by many factors such as the over use of nitrogen fertilizers in agriculture, the leaching of natural soil nitrate by the recharged water, nitrate-rich irrigation-return flow and septic tanks allowing the infiltration of the major part of the 
liquid phase. The potential genotoxicity of nitrates in the drinking water was previously investigated in the peripheral blood lymphocytes of children exposed to nitrate concentrations exceeding $70.5 \mathrm{mg} \mathrm{l}^{-1}$ (Tsezou et al., 2010).

Groundwater may also be contaminated by pesticides reaching groundwater through runoff and leaching. They can be harmful for the environment and human health. Pesticides including a wide variety of compounds belonging to different chemical classes, have been considered as inciters of gene mutation and micronuclei and chromosomal alteration (Bolognesi and Morasso, 2000; Sta et al., 2012; Goujon et al., 2014).

The sensitivity of the biomass endpoint was less than cell division and micronucleus induction. The cyto-mutagenicity/genotoxicity was not accompanied by notable changes in morphological and physiological parameters. Such sensitivity was previously pointed out in the Vicia roots exposed to Cd stress (Souguir et al., 2011) where cell division inhibition and micronucleus induction occurred soon after Cd exposure (12 h), prior to plasma membrane integrity and lipid peroxidation. Other authors thought that contaminants may disrupt microtubule arrays at a concentration lower than that causing root growth inhibition (Eun et al., 2000).

\section{Conclusion}

The analysis of the Teboulba groundwater revealed signs of genotoxicity in terms of mitotic index inhibition, micronucleus and abnormality induction. The micronuleus test using $V$. faba can be recommended as a fast, practical and reliable genotoxic assay for groundwater assessments. Genotoxic effects appeared while no changes of growth parameters (root elongation and plant biomass) and membrane integrity were found in treated plants compared to control plants, thus confirming the early sensitivity of the Vicia test to toxicity. The micronucleus test gave an idea about the effect of the whole contaminants present in the Teboulba groundwater. A more detailed study based on physico-chemical analyses of waters collected from different wells in the region should be carried out. Such analyses would allow to identifiy the harmful contaminants and to locate the anthropogenic sources. This could help the regional environmental services, local authorities, communities and industries to act responsibly against Teboulba groundwater contamination and to avoid further pollution.

Acknowledgements. The work was carried out under the PRM-IRESA project «Gestion Intégrée et Durable des Systèmes de Cultures Légumières Protégées (CléProD)». We would like to thank the Regional Commissariat for Agricultural Development of Monastir for the information support and the ease of access to farmers.

\section{REFERENCES}

[1] Achakzai, K., Khalid, S., Bibi, A. (2015): Determination of heavy metals in agricultural soil adjacent to functional brick kilns: a case study of Rawalpindi. - Science Technology and Development 34(3): 122-129.

[2] Ameur, M., Hamzaoui-Azaza, F., Gueddari, M. (2016): Nitrate contamination of Sminja aquifer groundwater in Zaghouan, northeast Tunisia: WQI and GIS assessments. Desalinsation and Water Treatment 57(50): 23698-23708. 
[3] Auerbach, C. (1962): Mutation: An introduction to research on mutagenesis Part I: Methods. - Oliver and Boyed, London.

[4] Bear, J., Cheng, A. H. D., Sorek, S., Quazar, D., Herrera, I. (1999): Seawater intrusion in coastal aquifers-Concepts, methods and practices. - Kluwer Academic Publishers, The Netherlands.

[5] Bear, J., Cheng, A. H. D. (2010): Modeling groundwater flow and contaminant transport. - Springer, The Netherlands.

[6] Beni-Akhy, R. (1998): Etude des impacts anthropiques sur les eaux souterraines du Sahel oriental tunisien: Caractérisation hydrogéologique, modélisation mathématique et cartographie de la vulnérabilité environnementale. - Thèse de Doctorat, Faculté des Sciences de Tunis, Tunisie (in French).

[7] Beraud, E., Cotelle, S., Leroy, P., Ferard, J. F. (2007): Genotoxic effects and induction of phytochelatins in the presence of cadmium in Vicia faba roots. - Mutation Research: 633(2): 112-116.

[8] Besbes, M., Chahed, H., Shayeb, H., Hamdane, A. (2013): L'eau en Tunisie. https://www.researchgate.net/publication/274069351_L\%27eau_en_Tunisie.

[9] Bignold, L. P. (2009): Mechanisms of clastogen-induced chromosomal aberrations: A critical review and description of a model based on failures of tethering of DNA strand ends to strand-breaking enzymes. - Mutation Researh 681: 271-298.

[10] Bolognesi, C., Morasso, G. (2000): Genotoxicity of pesticides: potential risk for consumers. - Trends Food Science Technology 11: 182-187.

[11] Bouri, S., Ben Dhia, H. (2010): A thirty-year artificial recharge experiment in a coastal aquifer in an arid zone: The Teboulba aquifer system (Tunisian Sahel). - Comptes Rendus Geoscience 342: 60-74.

[12] Chairi, R., Derenne, S., Abdeljaoued, S., Largeau, C. (2010): Sediment cores representative of contrasting environments in salt flats of the Moknine continental sabkha (Eastern Tunisia): Sedimentology, bulk features of organic matter, alkane sources and alteration. - Organic Geochemistry 41: 637-652.

[13] Chebil, A., Frija, A., Thabet, C. (2010): Irrigation water pricing between governmental policies and farmers' perception: Implications for green-houses horticultural production in Teboulba (Tunisia). - Agricultural Economics Review 11(2): 44-54.

[14] Cotelle, S., Dhyèvre, A., Muller, S., Chenon, P., Manier, N., Pandard, P., Echairi, A., Silvestre, J., Guiresse, M., Pinelli, E., Giorgetti, L., Barbafieri, M., Silva, V., Engel, F., Radetski, C. M. (2015): Soil genotoxicity Assessment-Results of an interlaboratory study on the Vicia micronucleus assay in the context of ISO standardization. - Environmental Science and Pollution Research 22: 988-995.

[15] CRDA. Commissariat Régional du Développement Agricole (2004): Rapport d'activité, Monastir (in French).

[16] Dahmouni, M., Hörmann, G., Hachicha, M. (2017): The Environmental impact of TWW on groundwater and drainage water in Tunisia. - Water Treatment 8: 1-2.

[17] Duan, P., Zhai, T., Xu, C., Ding, J., Chen, Y. (2013): A simple and effective method for detecting toxicity of chromium trioxide on Vicia faba. - European Food Research and Technology 236: 517-521.

[18] Einschlag, F. S. G. (2011): Waste Water - Evaluation and Management. - InTech-Open Access Publisher, Rijeka.

[19] Eun, S. O., Youn, H. S., Lee, Y. (2000): Lead disturbs microtubule organization in the root meristem of Zea mays. - Physiologia Plantarum 110: 357-365.

[20] Fenech, M., Kirsch-Volders, M., Natarajan, A. T., Surralles, J., Crott, J. W., Parry, J., Norppa, H. (2011): Molecular mechanisms of micronucleus, nucleoplasmic bridge and nuclear bud formation in mammalian and human cells. - Mutagenesis 26(1): 125-132.

[21] Fernandes, T. C., Mazzeo, D. E. C, Marin-Morales, M. A. (2007): Mechanism of micronuclei formation in polyploidizated cells of Allium cepa exposed to trifluralin herbicide. - Pesticide Biochemistry and Physiology 88: 252-259. 
[22] Fries, E., Mahjoub, O., Mahjoub, B., Berrehouc, A., Lions, J., Bahadir, M. (2016): Occurrence of contaminants of emerging concern (CEC) in conventional and nonconventional water resources in Tunisia. - Fresenius Environmental Bulletin 25(9): 3317-3339.

[23] Garg, V. K., Kaushik, P. (2007): Influence of textile mill wastewater irrigation on the growth of sorghum cultivars. - Applied Ecology and Environmental Research 6(2): 1-12.

[24] Goujon, E., Sta, C., Trivella, A., Goupil, P., Richard, C., Ledoigt, G. (2014): Genotoxicity of sulcotrione pesticide and photoproducts on Allium cepa root meristem. Pesticide Biochemistry and Physiology 113: 47-54.

[25] Hamed, Y., Awad, S., Ben Sâad, A. (2013): Nitrate contamination in groundwater in the Sidi Aïch-Gafsa oases region, Southern Tunisia. - Environmental Earth Sciences 70(5): 2335-2348.

[26] Majewsk, A., Wolska, E., Sliwinska, E., Furmanowa, M., Urbańska, N., Pietrosiuk, A., Zobel, A., Kuras, M. (2003): Antymitotic effect, G2/M accumulation, chromosomal and ultrastructure changes in meristematic cells of Allium cepa $\mathrm{L}$. root tips treated with the extract from Rhodiola rosea roots. - Caryologia 56(3): 337-351.

[27] Malarkodi, M., Krishnasamy, R., Kumaraperumal, R., Chitdeshwari, T. (2007): Characterization of heavy metal contaminated soils of Coimbatore district in Tamil Nadu. - Journal of Agronomy 6(1): 147-151.

[28] McLaughlin, M. J., Tiller, K. G., Naidu, R., Stevens, D. P. (1996): Review: the behaviour and environmental impact of contaminants in fertilizer. - Australian Journal of Soil Research 34: 1-54.

[29] Minhaz, A., Matsumoto, M., Kurosawa, K. (2018): Heavy Metal Contamination of Irrigation Water, Soil, and Vegetables in a Multi-industry District of Bangladesh. International Journal of Environmental Research 12(4): 531-542.

[30] Ouessar, M., Gabriels, D., Tsunekawa, A., Evett, S. (2017): Water and Land security in Dry lands. - Springer, Switzerland.

[31] Parry, E. M., Parry, J. M., Corso, C., Doherty, A., Haddad, F., Hermine, T. F., Johnson, G., Kayani, M., Quick, E., Warr, T., Williamson, J. (2002): Detection and characterization of mechanisms of action of aneugenic chemicals. - Mutagenesis 17(6): 509-521.

[32] Pourrut, B., Jeana, S., Silvestre, J., Pinelli, E. (2011): Lead-induced DNA damage in Vicia faba root cells: Potential involvement of oxidative stress. - Mutation Research 726: 123-128.

[33] Rafraf, I. D., Lekunberri, I., Sanchez-Melsi, A., Aouni, M., Borrego, C. M., Balcazar, J. L. (2016): Abundance of antibiotic resistance genes in five municipal wastewater treatment plants in the Monastir Governorate, Tunisia. - Environmental Pollution 219: 353-358.

[34] Rath, K. C., Sethi, B. (2017): Cytotoxic effect of silk dyeing industry effluents on the mitotic cells of Allium cepa. - European Journal of Zoological Research 5(2): 10-16.

[35] Saidi, S., Bouri, S., Ben Dhia, H. (2013): Groundwater management based on GIS techniques, chemical indicators and vulnerability to seawater intrusion modelling: application to the Mahdia-Ksour Essaf aquifer, Tunisia. - Environmental Earth Sciences 70: $1551-1568$.

[36] Sarker, B. C., Abdul Baten, M., Ekram, M., Haque, U. I. (2015): Heavy metals concentration in textile and garments industries wastewater of Bhaluka industrial area, Mymensingh, Bangladesh. - Current World Environment 10(1): 61-66.

[37] Souguir, D., Ferjani, E., Goupil, P., Ledoigt, G. (2008): Exposure of Vicia faba and Pisum sativum to copper- induced genotoxicity. - Protoplasma 233: 203-207.

[38] Souguir, D., Ferjani, E., Goupil, P., Ledoigt, G. (2011): Sequential effects of cadmium on genotoxicity and lipoperoxidation in Vicia faba roots. - Ecotoxicology 20: 329-336. 
[39] Souguir, D., Abd-Alla, H. I., Hörmann, G., Hachicha, M. (2018): Chromosomal and nuclear alterations in the root-tip cells of Vicia faba induced by sodium chloride. - Water Environment Research 90(2): 164-171.

[40] Souid, F., Agoubi, B., Hamdi, M., Telahigue, F., Kharroubi, A. (2017): Groundwater chemical and fecal contamination assessment of the Jerba unconfined aquifer, southeast of Tunisia. - Arabian Journal of Geosciences 10: 1-16.

[41] Sta, C., Ledoigt, G., Ferjani, E., Goupil, P. (2012): Exposure of Vicia faba to sulcotrione pesticide induced genotoxicity. - Pesticide Biochemistry and Physiology 103: 9-14.

[42] Steinkellner, H., Mun-Sik, K., Helma, C., Ecker, S., Ma, T., Horak, O., Kundi, M., Knasmuller, S. (1998): Genotoxic effects of heavy metals: comparative investigation with plant bioassays. - Environmental and Molecular Mutagenesis 31: 183-191.

[43] Sudhakar, R., Ninge Gowda, K. N., Venu, G. (2001): Mitotic abnormalities induced by silk dyeing industry effluents in the cells of Allium cepa. - Cytologia 66: 235-239.

[44] Teerarak, M., Bhinija, K., Thitavasanta, S., Laosinwattana, C. (2009): The impact of sodium chloride on root growth, cell division, and interphase silver- stained nucleolar organizer regions (AgNORs) in root tip cells of Allium cepa L. - Scientia Horticulturae 121: 228-232.

[45] Tsezou, A., Kitsiou-Tzeli, S., Calla, A., Gourgiotis, D., Papageorgiou, J., Mitrou, S. (1996): High Nitrate Content in Drinking Water: Cytogenetic Effects in Exposed Children. - Archives of Environmental Health 51(6): 458-461.

[46] Ünyayar, S., Çelik, A., Çekiç, F. O., Gözel, A. (2006): Cadmium-induced genotoxicity, cytotoxicity and lipid peroxidation in Allium sativum and Vicia faba. - Mutagenesis 21 (1): 77-81.

[47] Valverde, M., Trejo, C., Rojas, E. (2001): Is the capacity of lead acetate and cadmium chloride to induce genotoxic damage due to direct DNA-metal interaction? - Mutagenesis 16: $265-270$.

[48] Vega-Negron, A. L., Alamo, L., Perales-Perez, O., Gonzalez-Mederos, A. M., JusinoOlivencia, C., Roman-Velazquez, F. R. (2018): Simultaneous adsorption of cationic and anionic dyes by chitosan/cellulose beads for wastewaters treatment. - International Journal of Environmental Research 12(1): 59-65.

[49] Wakida, F. T., Lerner, D. N. (2005): Non-agricultural sources of groundwater nitrate: a review and case study. - Water Research 39(1): 3-16.

[50] Wali, A., Kawachi, A., Seddik, M., Bougi, M., Ben Dhia, H., Isoda, H., Tsujimura, M., Ksibi, M. (2015): Effects of metal pollution on sediments in a highly saline aquatic ecosystem: Case of the Moknine continental sebkha (Eastern Tunisia). - Bulletin of Environmental Contamination and Toxicology 94: 511-518.

[51] Yi, M., Yi, H., Li, H., Wu, L. (2010): Aluminum Induces Chromosome Aberrations, Micronuclei, and Cell Cycle Dysfunction in Root Cells of Vicia faba. - Environmental Toxicology 25(2): 124-129.

[52] Zghibi, A., Tarhouni, J., Zouhri, L. (2013): Assessment of seawater intrusion and nitrate contamination on the groundwater quality in the Korba coastal plain of Cap-Bon (Northeast of Tunisia). - Journal of African Earth Sciences 87: 1-12. 